\title{
Cell Surface Trk Receptors Mediate NGF-Induced Survival While Internalized Receptors Regulate NGF-Induced Differentiation
}

\author{
Yan-zhen Zhang, ${ }^{1,2}$ Daniel B. Moheban, ${ }^{1,2}$ Bevil R. Conway, ${ }^{1}$ Anita Bhattacharyya, ${ }^{3}$ and Rosalind A. Segal ${ }^{1,2}$ \\ ${ }^{1}$ Department of Neurobiology, Harvard Medical School, Boston, Massachusetts 02115, and Departments of 2 Pediatric \\ Oncology and ${ }^{3}$ Cancer Biology, Dana-Farber-Cancer Institute, Boston, Massachusetts 02115
}

\begin{abstract}
Internalization and transport of a ligand-receptor complex are required to initiate cell body responses to target-derived neurotrophin. However, it is not known whether internalized receptors and cell surface receptors initiate the same signaling pathways and biological responses. Here we use a temperature-sensitive mutant of dynamin (G273D) to control the subcellular localization of activated NGF receptors (Trks). We show that dynamin function is required for ligand-dependent endocytosis of Trk receptors. In PC12 cells, nerve growth factor (NGF) stimulation promotes both survival and neuronal differentiation. These distinct biological responses to NGF are controlled by receptors signal-
\end{abstract}

ing from different locations within the cell. Neuronal differentiation is promoted by catalytically active Trks within endosomes in the cell interior. In contrast, survival responses are initiated by activated receptors at the cell surface where they orchestrate prolonged activation of the kinase Akt. Thus, interactions between Trk receptor tyrosine kinases and intracellular signaling molecules are dictated both by phosphotyrosine motifs within the receptors and by the intracellular location of phosphorylated receptors.

Key words: nerve growth factor; neurotrophin; receptor tyrosine kinase; dynamin; endocytosis; survival; Akt
Peptide growth factors, such as the neurotrophins, bind to specific receptor tyrosine kinases (Trks) located at the plasma membrane of responsive cells. Formation of the ligand-receptor complex induces, or stabilizes, the formation of receptor oligomers and activates the receptor's intrinsic tyrosine kinase activity. The receptor subunits then autophosphorylate in trans specific phosphotyrosine residues within the receptor. The activated receptor subunits become scaffolding for assembly of a multi-enzyme signal-generating complex (Lemmon and Schlessinger, 1994).

Formation of the ligand-receptor complex also initiates internalization of the activated receptor into vesicles. Receptors internalized into vesicles remain activated for as long as the ligand remains associated with receptor (Bergeron et al., 1995). However, the signal-generating proteins and their substrates are not uniformly distributed within the cytosol. Therefore, individual components of the signal cascades might be used selectively during transit from the outer cell surface to the interior of the cell.

The effect of internalization on receptor signaling is particularly relevant in considering biological responses to neurotrophins. During development, many target tissues synthesize neurotrophinsnerve growth factor (NGF), brain-derived neurotrophic factor, neurotrophin 3 or neurotrophin $4 / 5$, while presynaptic neurons that contact the target express the corresponding receptor tyrosine kinases and require target-derived neurotrophin for survival and differentiation. Recent studies indicate that internalization and transport of the ligand-receptor complex are required to initiate cell body responses to target-derived neurotrophin (Ehlers et al., 1995; Bhattacharyya et al., 1997; Riccio et al., 1997; Senger and Campenot, 1997; Tsui-Pierchala and Ginty, 1999; Watson et al., 1999a). Furthermore, studies performed both in vivo and in vitro have demonstrated that neurotrophin receptors (Trks) internalized

Received Dec. 15, 1999; revised May 12, 2000; accepted May 17, 2000.

This work was supported by a grant from National Institutes of Health (NS35148), fellowships from the Swedish Medical Research Council (Y.Z.Z.) and the Natural Sciences and Engineering Research Council of Canada (B.R.C.), and the Robert Ebert Fellowship from the Klingenstein Foundation (R.A.S.). We thank Chuck Stiles, Andrius Kazlauskas, Mike Greenberg, and Yvonne Yannoni for helpful comments. The NGF used in these studies was a generous gift from Andrew Welcher (Amgen, Inc., Thousand Oaks, CA).

Correspondence should be addressed to Dr. Rosalind Segal, Department of Pediatric Oncology, Dana Farber Cancer Institute, 44 Binney Street, Boston, MA 02115. E-mail: rosalind_segal@dfci.harvard.edu.

Copyright (C) 2000 Society for Neuroscience $0270-6474 / 00 / 205671-08 \$ 15.00 / 0$ into vesicles remain activated (Ehlers et al., 1995; Grimes et al., 1996; Bhattacharyya et al., 1997; Grimes et al., 1997).

Receptor tyrosine kinases are primarily internalized into clathrin-coated vesicles (Bergeron et al., 1995). Thus, mutations of the endocytic proteins, dynamin and clathrin, inhibit internalization of EGF or insulin receptors (Vieira et al., 1996; Ceresa et al., 1998). Here we used a conditional mutant of dynamin (Damke et al., 1995) to change the location of activated NGF receptors (Trk A) in PC12 cells. We chose this system because PC12 cells show multiple and distinct biological responses to NGF, including growth arrest, survival, and differentiation (Greene and Tischler, 1982). In PC12 cells expressing the temperature-sensitive mutant of dynamin (G273D) (Damke et al., 1995), we can acutely regulate endocytosis of Trk receptors by changing from the permissive to nonpermissive temperature. We show that survival is maximally regulated by NGF receptors localized at the plasma membrane, via prolonged activation of the PI3 kinase/Akt signaling pathway. In contrast, differentiation is stimulated by catalytically active NGF receptors in vesicles. Taken together, these data indicate that the location of activated receptors is a critical regulator of biological responses and signaling pathways.

\section{MATERIALS AND METHODS}

Reagents. Recombinant NGF was a gift from Dr. Andrew Welcher (Amgen, Thousand Oaks, CA). High molecular weight marker proteins were purchased from Life Technologies (Gaithersburg, MD). Acrylamide was purchased from National Diagnostic (Atlanta, GA). The antibodies used were to pMEK (Calbiochem-Novabiochem Corporation, San Diego, CA), pErk (Promega, Madison, WI), Phospho-Akt Ser473 (pAKT; New England Biolabs, Beverly, MA), pCREB (Dr. Michael E. Greenberg, Children's Hospital, Boston), hemaglutinin (HA; Boehringer Mannheim, Indianapolis, IN), dynamin (Upstate Biotechnology, Lake Placid, NY), peripherin (Chemicon, Temecula, CA), and the extracellular domain of TrkA (Zymed Laboratories, San Francisco, CA). Site-specific antibodies to Phospho-Trk and an antibody to C-terminal Trk peptide (pan Trk) have been described previously (Segal et al., 1996). Streptavidin-Cy3, goat anti-mouse secondary antibodies conjugated with biotin, and anti-mouse or anti-rabbit secondary antibodies conjugated with alkaline phosphatase were obtained from Jackson ImmunoResearch (West Grove, PA). ${ }^{125}$ INGF was purchased from Amersham Pharmacia Biotech (Arlington, IL).

Generation of dynamin-expressing PC12 cells. HA-tagged TS-dynamin (G273D), wild-type dynamin, and a dominant negative dynamin (K44A) were obtained from Dr. Sandra Schmid (Scripps Research Institute, La Jolla, CA) (Damke et al., 1995), subcloned into pCDNA3 vector, and introduced into PC12 cells using calcium phosphate transfection (Dudek et al., 1997). Positive clones were selected, grown, and expanded in $200 \mu \mathrm{g} / \mathrm{ml}$ 
G418. Cell lines expressing dominant negative dynamin grew slowly and only expressed low levels of mutant protein. Therefore, further analysis was restricted to four temperature-sensitive (TS) and two wild-type (WT) dynamin-expressing clones, each expressing 1.5-3 times the level of dynamin seen in the parental PC12 cell line.

Internalization assays. Internalization of NGF was measured using biotinylated NGF or ${ }^{125}$ I-NGF. Biotinylated NGF was prepared using the Pierce EZ-Link NHS-LC biotinylation kit, according to the manufacturer's instructions, and dialyzed to remove unconjugated biotin. Biotinylated NGF was tested for bioactivity in a PC12 survival assay; biotinylated NGF induced PC12 cell survival in serum-free medium at $1 \mathrm{ng} / \mathrm{ml}$. Biotinylation of NGF was confirmed by immunoblot with avidin-peroxidase. Cells were shifted to the indicated temperature $15 \mathrm{~min}$ before stimulation. After stimulation with biotinylated NGF $(100 \mathrm{ng} / \mathrm{ml})$, cultures were fixed with $2 \%$ paraformaldehyde, permeabilized with $0.5 \% \mathrm{NP}-40$ or not as indicated, and visualized with streptavidin Cy-3.

To allow quantitation of NGF internalization, uptake of ${ }^{125}$ I-NGF was assayed. In the standard internalization assay (Eveleth and Bradshaw, 1992), ${ }^{125} \mathrm{I}-\mathrm{NGF}$ is allowed to bind at $4^{\circ} \mathrm{C}$, then cells are warmed for various times and internalization is measured. Under these conditions, the kinetics of internalization in the TS-dynamin cell lines were similar to previously published measures for PC12 cells. However, because internalization occurs during the period of warming from 4 to $39^{\circ} \mathrm{C}$, no temperature effects could be evaluated in this manner. Therefore, we used an assay in which binding and internalization occur simultaneously. Cells were shifted to the indicated temperature $20 \mathrm{~min}$ before stimulation with ${ }^{125} \mathrm{I}-$ NGF. Then cells were incubated at the indicated temperature in ${ }^{125} \mathrm{I}-\mathrm{NGF}$ $(0.4 \mu \mathrm{Ci} / \mathrm{ml})$, alone or with excess $\mathrm{NGF}(200 \mathrm{ng} / \mathrm{ml})$, and $0.1 \mathrm{mg} / \mathrm{ml} \mathrm{BSA}$. At the indicated times, the cells were washed on ice, and surface ${ }^{125} \mathrm{I}-\mathrm{NGF}$ was removed with two acid washes $(0.2 \mathrm{~N}$ acetic acid, $0.5 \mathrm{M} \mathrm{NaCl})$, then internalized ${ }^{125} \mathrm{I}-\mathrm{NGF}$ was solubilized in $10 \mathrm{~mm}$ Tris, $1 \%$ SDS. Specific internalization (internalized ${ }^{125} \mathrm{I}-\mathrm{NGF}$ minus internalized ${ }^{125} \mathrm{I}-\mathrm{NGF}$ with excess NGF) was assessed for each temperature at 0 and $120 \mathrm{~min}$. Triplicate cultures were assayed for each point.

To assay internalization of Trk receptors, cells were placed at 33 or $39^{\circ} \mathrm{C}$ for $15 \mathrm{~min}$, then treated with NGF $(100 \mathrm{ng} / \mathrm{ml})$ or vehicle control $(0.1$ $\mathrm{mg} / \mathrm{ml} \mathrm{BSA}$ ) for $15 \mathrm{~min}$. Cells were fixed with $2 \%$ paraformaldehyde permeabilized with $0.5 \%$ NP-40 or not as indicated, and immunostained with a monoclonal antibody to the extracellular domain of TrkA (1:1000), visualized with biotinylated secondary antibody and streptavidin Cy-3. Random images were captured in Adobe Photoshop using a Spot camera and Nikon fluorescence microscope. Images were imported into NIH Image, and the fluorescence intensity per cell was assessed for 40-100 cells per condition by an observer blinded for the assay conditions. Data are expressed as the average of the fluorescence intensity for each unpermeabilized cell divided by the average fluorescent intensity of permeabilized cells under the same conditions. This provides a measure of the percentage of the Trk receptor that is on the cell surface. Temperature did not affect the fluorescence intensity seen in the permeabilized cells. Controls omitting primary antibody showed no detectable signal.

Survival. Three assays were used to monitor NGF-dependent survival. Cells were plated on coverslips at $5 \times 10^{5}$ cells per well in 24 -well plates, allowed to attach for $6 \mathrm{hr}$, serum-starved for $45 \mathrm{~min}$ at $33^{\circ} \mathrm{C}$ and for $15 \mathrm{~min}$ at the indicated temperature, then treated with $50 \mathrm{ng} / \mathrm{ml} \mathrm{NGF}$ or vehicle control (DME with $0.1 \mathrm{mg} / \mathrm{ml} \mathrm{BSA}$ ) for $24 \mathrm{hr}$. Cells were fixed, and dying cells were visualized by terminal deoxynucleotidyl transferase-mediated biotinylated dUTP nick end labeling (TUNEL) staining (Gavrieli et al. 1992; Schwartz et al., 1997). For lactate dehydrogenase (LDH) and 3-(4,5dimethylthiazol-2-yl)-2,5-diphenyltetrazolium bromide (MTT) assays of viable cells, cells were plated at $2 \times 10^{4}$ cells per well on 96 -well plates, then treated with NGF or vehicle control for $24 \mathrm{hr}$. Viable cells were determined using the MTT assay kit (Boehringer Mannheim) or LDH assay kit (Promega) according to the manufacturers' directions.

Neurite outgrowth. Cells were plated at $5 \times 10^{3}$ or $5 \times 10^{4}$ cells per 35 $\mathrm{mm}$ dish, shifted to the indicated temperature for $15 \mathrm{~min}$, then treated with $50 \mathrm{ng} / \mathrm{ml} \mathrm{NGF}$ or vehicle control in DME alone, or in DME with serum, for $3 \mathrm{~d}$ at the indicated temperature. The percentage of cells with neurites (defined as a process greater than twice the cell body size) was determined for each condition.

Proliferation. Cells were plated at $2 \times 10^{4}$ cells per well of a 24 -well plate in complete medium. After $18 \mathrm{hr}$ at $33^{\circ} \mathrm{C}$, cells were shifted to the indicated temperature and treated with $50 \mathrm{ng} / \mathrm{ml} \mathrm{NGF}$ or vehicle control in DME with $10 \mu \mathrm{M}$ bromodeoxyuridine (BrdU). At $24 \mathrm{hr}$, cells were fixed, then stained with anti-BrdU (Boehringer Mannheim) according to the manufacturer's directions. The treatment with $\mathrm{HCl}$ was limited to $10 \mathrm{~min}$. Cells were counterstained with 4,6 diamidino-2-phenyl-indole. The percentage of nuclei that were BrdU-positive was calculated for three to six coverslips per condition by an observer blinded for the assay conditions.

Immunoblot analysis. TS-dynamin and WT-dynamin PC12 cells were serum-starved for $45 \mathrm{~min}$ at $33^{\circ} \mathrm{C}$, then for $15 \mathrm{~min}$ at the indicated temperatures. Cells were stimulated with NGF or vehicle control as indicated, then lysed in $20 \mathrm{~mm}$ Tris, pH 7.4, $137 \mathrm{~mm} \mathrm{NaCl}, 1 \%$ SDS, $10 \%$ glycerol, 5\% $\beta$-mercaptoethanol containing $1 \mathrm{~mm}$ phenylmethylsulfonylfluoride, $1 \mathrm{~mm}$ leupeptin, $10 \mu \mathrm{g} / \mathrm{ml}$ aprotinin, and $1 \mathrm{~mm} \mathrm{Na}$ orthovanadate on ice. Equal amounts of protein lysates were size-fractionated through a $10 \%$ SDS-acrylamide gel and transferred to Immobilon-P membrane (Millipore, Bedford, MA). The blots were incubated with primary antibodies, processed with secondary antibodies, and visualized using the chemifluorescence (ECF) kit (Amersham) in conjunction with the Storm System (Molecular Dynamics, Sunnyvale, CA). Final images were processed in Adobe Photoshop.

Kinase assay. TS-dynamin and WT-dynamin PC12 cells were serumstarved for $45 \mathrm{~min}$ at $33^{\circ} \mathrm{C}$, then for $15 \mathrm{~min}$ at the indicated temperatures. Cells were stimulated for the indicated times with $50 \mathrm{ng} / \mathrm{ml} \mathrm{NGF}$ and harvested in lysis buffer (20 mM Tris, pH 8, $137 \mathrm{~mm} \mathrm{NaCl}, 1 \% \mathrm{NP}-40,10 \%$ glycerol, $50 \mathrm{mM} \mathrm{NaF}, 10 \mathrm{mM}$ pyrophosphate, $1 \mathrm{mM}$ PMSF, $10 \mu \mathrm{g} / \mathrm{ml}$ aprotinin, $20 \mu \mathrm{M}$ leupeptin, $1 \mathrm{~mm} \mathrm{Na}$ orthovanadate). Extracts were immunoprecipitated with anti-pan Trk at a 1:100 dilution. Extracts and antibody were incubated for $2 \mathrm{hr}$ at $4^{\circ} \mathrm{C}$. Fifty microliters of Protein A Sepharose beads (Pharmacia Biotech, Uppsala, Sweden) in $20 \mathrm{~mm}$ Tris, preincubated with $10 \%$ BSA, were added to the extracts and incubated for $1 \mathrm{hr}$ at $4^{\circ} \mathrm{C}$. Immunoprecipitates were washed once with lysis buffer, twice with $1 \mathrm{M} \mathrm{LiCl}$ in $20 \mathrm{~mm}$ Tris, and once in kinase buffer $(10 \mathrm{~mm}$ Tris, $\mathrm{pH} 7.4$, $10 \mathrm{~mm} \mathrm{MnCl}_{2}$ ). Immunoprecipitates were incubated with $30 \mu \mathrm{Ci} \gamma^{-32} \mathrm{P}$ ATP in $30 \mu \mathrm{l}$ kinase buffer containing $50 \mu \mathrm{M}$ Trk substrate peptide (CGMSRDV YSTDYYRVGG) and $5 \mu \mathrm{M}$ cold ATP for $20 \mathrm{~min}$ at room temperature. After addition of sample buffer, samples were boiled and size-fractionated on $15 \%$ SDS-polyacrylamide gels. Dried gels were visualized and quantified using the Storm System (Molecular Dynamics).

\section{RESULTS}

\section{NGF and Trk internalization are dynamin dependent}

NGF-dependent Trk internalization was analyzed in PC12 cells transfected with HA-tagged versions of wild-type (WT) dynamin I or a temperature-sensitive (TS) dynamin I mutant (G273D). The G273D dynamin is expressed at both the permissive $\left(33^{\circ} \mathrm{C}\right)$ and nonpermissive temperatures $\left(39^{\circ} \mathrm{C}\right)$, but it becomes a dominant negative isoform within minutes at the nonpermissive temperature (Damke et al., 1995). Therefore, by changing the temperature 15 min before NGF stimulation, we can acutely inactivate dynamin at the time of stimulation by NGF.

To determine whether dynamin can regulate endocytosis of Trk receptors, we first examined internalization of NGF tagged with biotin. TS-dynamin PC12 cells at the permissive $\left(33^{\circ} \mathrm{C}\right)$ or nonpermissive $\left(39^{\circ} \mathrm{C}\right)$ temperature were treated with biotinylated NGF for $2 \mathrm{hr}$, then fixed and stained with streptavidin-Cy3 to visualize bound NGF. Parallel cultures at the two temperatures were fixed, permeabilized, and then stained to visualize internalized NGF. As shown in Figure $1 a$, NGF internalization can be seen at the permissive temperature $\left(33^{\circ} \mathrm{C}\right)$ but is inhibited at the nonpermissive temperature $\left(39^{\circ} \mathrm{C}\right)$, indicating that dynamin function is needed for NGF internalization. To determine the extent to which dynamin inhibited NGF internalization, we repeated the internalization assay using ${ }^{125} \mathrm{I}-\mathrm{NGF}$. As shown in Figure $1 b$, at the nonpermissive temperature $\left(39^{\circ} \mathrm{C}\right)$, specific internalization of NGF is inhibited by $30 \%$ when compared with internalization at the permissive temperature. At the nonpermissive temperature, NGF internalization is inhibited to the same extent as when cells are held at $4^{\circ} \mathrm{C}$, the classic method for blocking internalization. These data indicate that dynamin is required for NGF internalization.

Because PC12 cells express two distinct NGF receptors, p75 and TrkA (Hosang and Shooter, 1985; Chao, 1992), dynamindependent internalization of NGF could reflect basal endocytosis, p75 receptor-mediated internalization, or Trk-mediated internalization. To determine whether dynamin is specifically required for NGF-mediated TrkA internalization, we used an antibody to the extracellular domain of TrkA to visualize cell surface receptors. TS-dynamin PC12 cells were treated with NGF $(100 \mathrm{ng} / \mathrm{ml})$ or vehicle control, fixed, and immunostained with an antibody to the extracellular domain of TrkA, followed by a biotinylated secondary antibody and avidin-Cy3 (Fig. 1c). In the absence of permeabilization, this procedure selectively visualizes receptors at the cell surface. In parallel experiments, cells were fixed and permeabilized before they were stained with an antibody to the extracellular domain of TrkA, followed by a biotinylated secondary antibody and avidin-Cy3. After permeabilization, this procedure visualizes both the surface and the intracellular TrkA receptors.

To quantify the level of surface TrkA, images of permeabilized or unpermeabilized cells stained with the antibody to the extracellular domain of TrkA were acquired with a CCD camera and 
a.
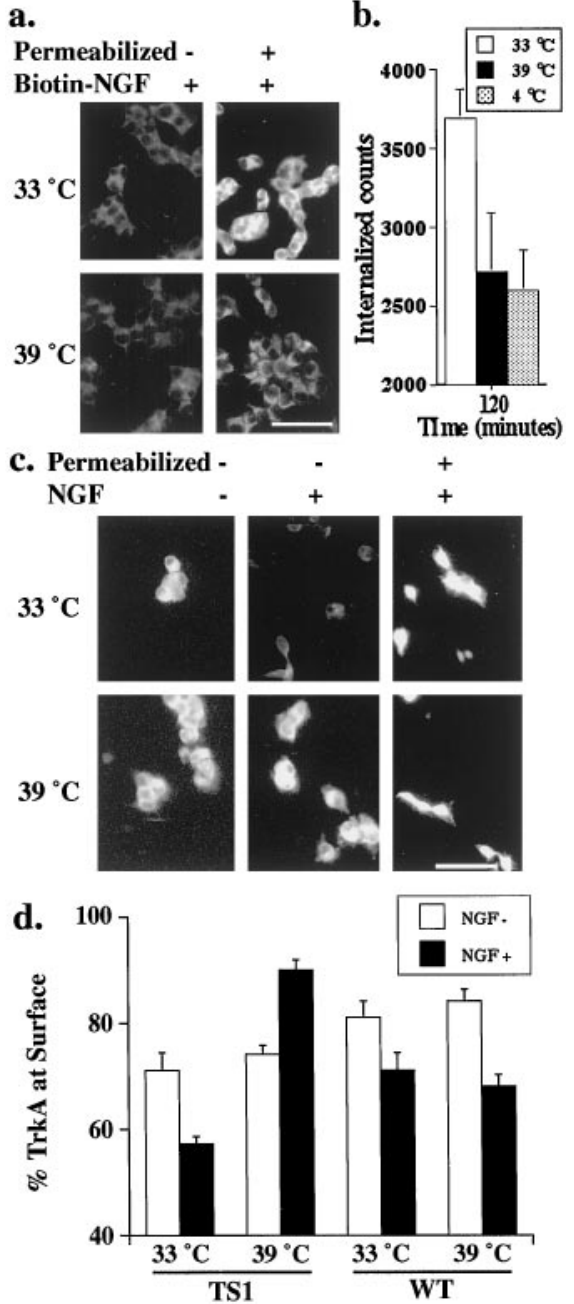

Figure 1. Dynamin is required for internalization of NGF and TrkA. $a$, TS-dynamin PC12 cells were stimulated with biotin-tagged NGF for $2 \mathrm{hr}$ at the indicated temperatures, then fixed and permeabilized (Permeabilized) or not. Accessible biotin was visualized with streptavidin-Cy3. Scale bar, 50 $\mu \mathrm{m} . b$, TS-dynamin PC12 cells were stimulated with ${ }^{125} \mathrm{I}-\mathrm{NGF}$ alone or with excess unlabeled NGF for $2 \mathrm{hr}$ at the indicated temperatures. Specific internalized counts $\left({ }^{125} \mathrm{I}-\mathrm{NGF}\right.$ internalized minus ${ }^{125} \mathrm{I}-\mathrm{NGF}$ internalized in the presence of $200 \mathrm{ng} / \mathrm{ml} \mathrm{NGF}$ ) were similarly decreased at the nonpermissive temperature and when internalization was blocked at $4^{\circ} \mathrm{C}$. $c$, TSdynamin PC12 cells were stimulated with NGF $(N G F+)$ or vehicle control $(N G F-)$ for 15 min at the indicated temperature, then fixed and permeabilized (Permeabilized) or not. Cells were immunostained with anti-TrkA, followed by biotinylated secondary antibody and streptavidin-Cy3. Scale bar, $50 \mu \mathrm{m}$. $d$, Intensity of TrkA immunostaining was measured at 33 and $39^{\circ} \mathrm{C}$ for TS-dynamin or WT-dynamin PC12 cells 15 min after stimulation with NGF $(+)$ or vehicle control $(-)$. Values are mean surface TrkA per cell $( \pm$ SEM) for each condition, normalized to total TrkA per cell. NGF induces a decrease in the percentage of TrkA at the surface at both temperatures in WT-dynamin cells. In TS-dynamin cells, NGF induces a decrease in surface TrkA at the permissive but not at the nonpermissive temperature $(p<0.001)$. Paired $t$ test was used to compare surface TrkA at the permissive and nonpermissive temperatures.

imported into NIH Image. The fluorescence intensity per cell was assessed for 40-100 cells per condition by an observer blinded for the assay conditions. The data are expressed as the percentage of TrkA that is on the cell surface (mean of the fluorescent intensity for each unpermeabilized cells divided by the average fluorescent intensity of permeabilized cells for each condition). Before stimulation, the level of TrkA at the cell surface is the same at the permissive $\left(33^{\circ} \mathrm{C}\right)$ and nonpermissive temperature $\left(39^{\circ} \mathrm{C}\right)$. Within 15 min of NGF stimulation, the amount of cell surface TrkA is reduced at the permissive temperature $\left(33^{\circ} \mathrm{C}\right)$ but remains high at the nonpermissive temperature $\left(39^{\circ} \mathrm{C}\right)$. In this assay, NGF stimulation leads to the internalization of $36 \pm 3 \%$ of the cell surface

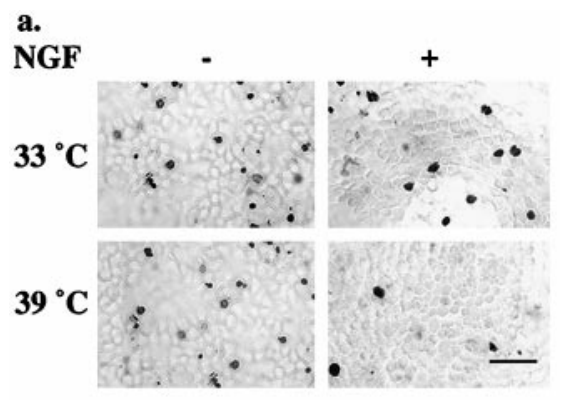

b.

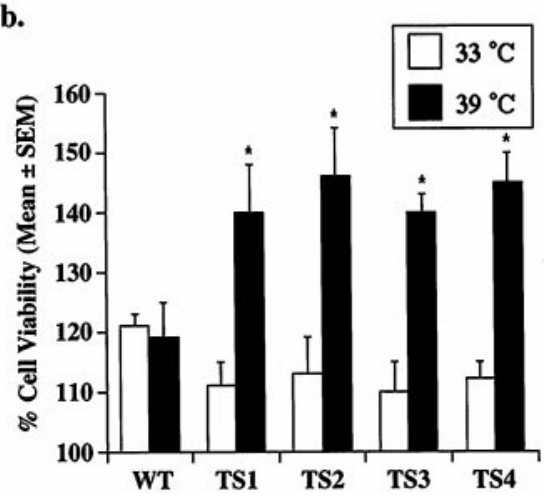

Figure 2. Inhibition of internalization enhances NGF-dependent survival. $a$, TS-dynamin PC12 cells were incubated in serum-free media with NGF $(+\mathrm{NGF})$ or vehicle control ( $-\mathrm{NGF}$ ) for $24 \mathrm{hr}$ at the indicated temperatures. Dying cells were visualized by TUNEL stain. Scale bar, $50 \mu \mathrm{m}$. $b$, TSdynamin PC12 lines (TS1-TS4) and wild-type dynamin PC12 cells (WT) were incubated in serum-free media with NGF $(+\mathrm{NGF})$ or vehicle control $(-\mathrm{NGF})$ for $24 \mathrm{hr}$ at the indicated temperatures. Relative cell viability for each condition was assessed by LDH activity normalized to vehicle control. Each data point represents mean values $( \pm$ SEM) from six separate experiments. Wilcoxon signed rank test was used to compare results at the two temperatures. ${ }^{*} p<0.05$.

TrkA, which is in close agreement with previous measures of NGF-induced internalization in PC12 cells (Beattie et al., 1996). Similar results are seen in all TS-dynamin cell lines, but Trk internalization is not temperature dependent in clones expressing wild-type dynamin (Fig. 1d).

To ensure that the dynamin-dependent difference in cell surface staining reflects a difference in TrkA localization and not in TrkA levels, NGF-treated cells were permeabilized and then stained to visualize total cellular TrkA. After permeabilization, there is no difference in the level of TrkA staining at the permissive and nonpermissive temperatures (Fig. 1c) (quantitative analysis not shown). These data indicate that dynamin function is required for NGF-induced endocytosis of TrkA, and so the TS-dynamin mutation can be used to regulate acutely the location of activated Trk receptors.

It is interesting to note that in the absence of NGF stimulation, the surface TrkA levels were the same at the permissive and nonpermissive temperatures. Thus, dynamin may not be required for the endocytosis of unliganded receptors, or else the rate of endocytosis of unstimulated TrkA receptors is too low to detect in these experiments.

\section{Biological effects of blocking Trk internalization}

NGF stimulation of PC12 cells promotes survival and also induces neuronal differentiation (Greene and Tischler, 1982). To determine the effect of altering Trk localization on NGF responses, we first monitored NGF-dependent survival of the TS-dynamin PC12 cells. Unstimulated cells die at both the permissive and nonpermissive temperatures, and NGF increases survival at both temperatures (Fig. 2a). However, after $24 \mathrm{hr}$ of NGF treatment, the number of apoptotic cells visualized by TUNEL staining is greater at the permissive $\left(33^{\circ} \mathrm{C}\right)$ temperature than at the nonpermissive temperature $\left(39^{\circ} \mathrm{C}\right)$ (Fig. $\left.2 a\right)$. Using three distinct assays to monitor 
NGF-dependent survival-a TUNEL assay (Fig. 2a), an LDH assay (Fig. 2b), and a MTT assay (data not shown)-we consistently find that NGF-stimulated survival was improved at the nonpermissive temperature in all of the TS-dynamin clones. No temperature effect is seen in the parental cell line or in WTdynamin clones (Fig. $2 b$ ). These data indicate that inhibition of Trk internalization enhances NGF-dependent survival.

Surprisingly, opposite results are seen when neurite outgrowth, a measure of neuronal differentiation, was monitored in the TSdynamin PC12 cells. As shown in Figure $3 a$, within $3 \mathrm{~d}$ of stimulation NGF induces neurites in the TS-dynamin PC12 cells at the permissive temperature $\left(33^{\circ} \mathrm{C}\right)$. Neurite growth and cell rounding in these cells is similar to that seen in wild-type dynamin PC12 cells and in the parental cell line (data not shown). However, at the nonpermissive temperature $\left(39^{\circ} \mathrm{C}\right)$, NGF-induced neurite outgrowth and rounding up of the cell bodies were inhibited in the TS-dynamin clones. Similar results were obtained with all TSdynamin clones in the presence or absence of serum, but no effect of temperature was seen in parental PC12 cells or WT-dynamin clones (Fig. 3b).

Dynamin might be required for neurite outgrowth per se (Torre et al., 1994), independent of any effect on NGF-induced differentiation. Therefore, we examined the effect of the dynamin mutation on another marker of NGF-induced differentiation, expression of the intermediate filament protein peripherin (Aletta et al., 1988). In PC12 cells, expression of peripherin is a marker of neuronal differentiation that is independent of neurite outgrowth (Troy et al., 1992). Consistent with previous studies in PC12 cells, NGF treatment of TS-dynamin PC12 cells increases peripherin levels. Analogous to the effects of the dynamin mutant on neurite outgrowth, we found that the increase in peripherin induced by $3 \mathrm{~d}$ of treatment with NGF is greater at the permissive temperature $\left(33^{\circ} \mathrm{C}\right)$ than at the nonpermissive temperature $\left(39^{\circ} \mathrm{C}\right)$ in all $\mathrm{TS}$ dynamin clones. Mean peripherin levels were increased by $60 \pm$ $14 \%$ at the permissive temperature, but only by $30 \pm 13 \%$ at the nonpermissive temperature $(p<0.05)$. Temperature did not alter NGF induction of peripherin expression in WT-dynamin PC12 cells, and in the absence of NGF, basal levels of peripherin fluctuate with time in culture in both WT and TS-dynamin clones (data not shown). Thus endocytosis potentiates two measures of NGFdependent differentiation: neurite outgrowth and peripherin expression. Taken together, these data indicate that receptor internalization attenuates $\mathrm{NGF}$-dependent survival responses but promotes NGF-dependent differentiation.

Neuronal differentiation can be prevented during cell proliferation. Therefore we assessed the effects of temperature on proliferation in the TS-dynamin cells. Cells were plated in DME, or DME with NGF for $24 \mathrm{hr}$, together with bromodeoxyuridine. In serumfree medium in the absence of NGF, similar percentages of cells incorporate $\mathrm{BrdU}$ at the permissive and nonpermissive temperatures. In the presence of NGF, there is a small increase in proliferation at both the permissive and nonpermissive temperatures, and there is no statistically significant effect of temperature on proliferation (Fig. 3c). Thus blocking endocytosis inhibits NGFinduced differentiation independent of changes in proliferation. Of note, when proliferation was assessed in serum-containing media, the percentage of cells that incorporate bromodeoxyuridine was greater at the nonpermissive temperature $\left(39^{\circ} \mathrm{C}\right)$ both in the presence and absence of NGF (data not shown). This is consistent with previous reports that EGF-induced proliferation is potentiated when endocytosis is inhibited (Vieira et al., 1996).

\section{Does internalization alter receptor phosphorylation and kinase activity?}

To initiate biological responses, activated Trk receptors phosphorylate themselves on several distinct tyrosine residues, and the phosphorylation states of individual sites are differentially regulated (Segal et al., 1996). To determine whether internalization selectively alters the phosphorylation state at particular tyrosine residues, we used phospho-specific antibodies (Segal et al., 1996) to
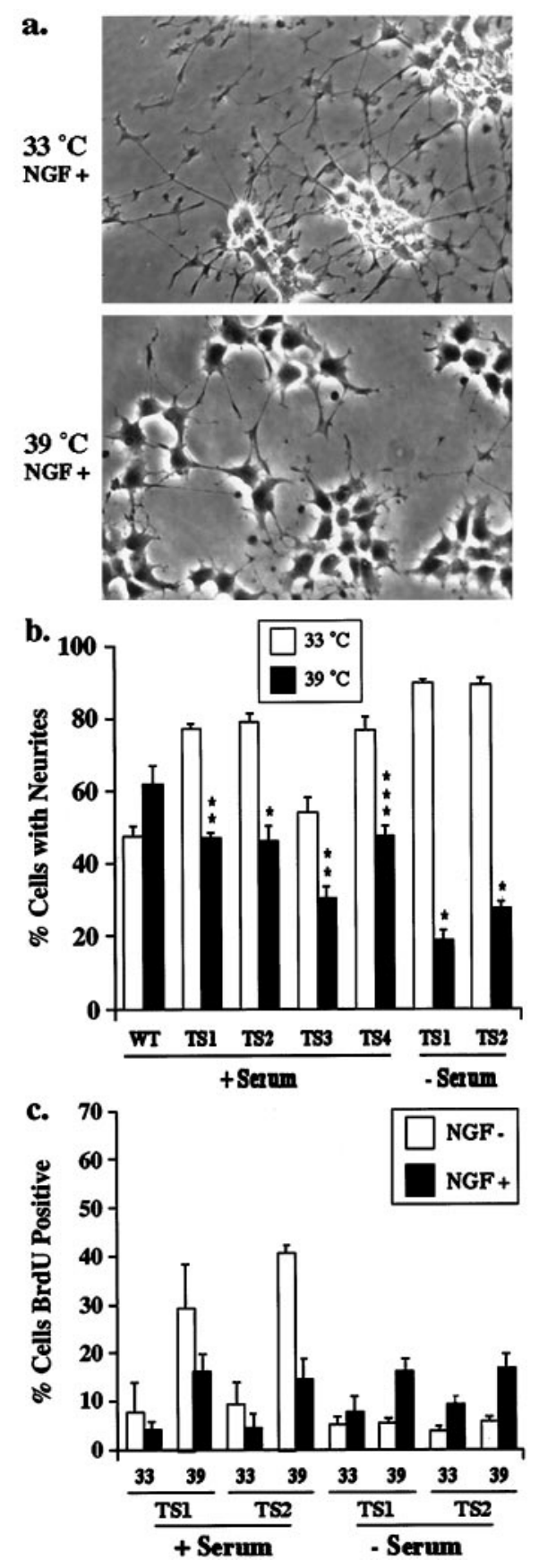

Figure 3. Trk internalization promotes neuronal differentiation. $a$, TSdynamin and wild-type dynamin cells were incubated in DME with NGF $(N G F+)$ for $3 \mathrm{~d}$ at the indicated temperatures, then visualized with a phase-contrast microscope. Representative examples of the TS-dynamin cells are shown. Scale bar, $50 \mu \mathrm{m}$. $b$, The percentage of cells with neurites was assessed for each condition. Each data point represents mean values of two to five separate experiments ( \pm SEM). Wilcoxon signed rank test was used to compare results at the two temperatures. ${ }^{*} p<0.05, * * p<0.01$, $* * * p<0.001$. $c$, TS-dynamin PC12 cells were cultured in DME alone or with $50 \mathrm{ng} / \mathrm{ml} \mathrm{NGF}$, or in DME with serum alone or with $50 \mathrm{ng} / \mathrm{ml} \mathrm{NGF}$ for $24 \mathrm{hr}$ in the presence of bromodeoxyuridine. At $24 \mathrm{hr}$, the cultures were fixed, and the percentage of cell nuclei labeled with BrdU was assessed for each condition. Wilcoxon signed rank test was used to compare results at the two temperatures.

examine the time course of Trk phosphorylation at Y490, the Shc binding site, and Y674/675, the activation loop sites. Internalization does not affect phosphorylation at the Y490 Shc binding site (Fig. $4 a, c)$. However, NGF-induced phosphorylation at the activation loop sites, Y674/675, is greater at the permissive temperature $\left(33^{\circ} \mathrm{C}\right)$ than at the nonpermissive temperature $\left(39^{\circ} \mathrm{C}\right)$ after 15 and 
a.

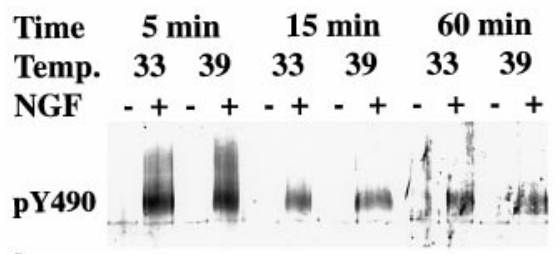

b.

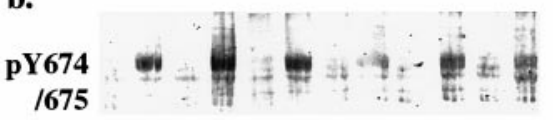

c. pY490

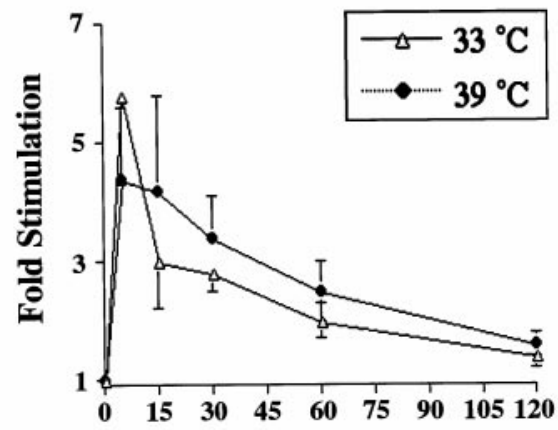

d. pY674/675

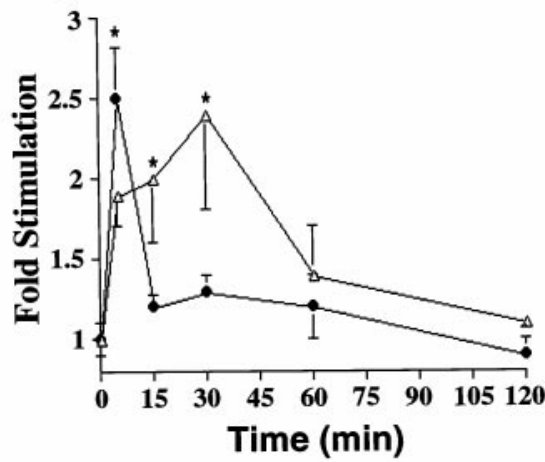

Figure 4. Phosphorylation state of activation loop tyrosines is regulated by internalization. $a, b$, TS-dynamin PC12 cells were stimulated with NGF $(+)$ or vehicle control $(-)$ for the indicated times at the indicated temperature. Phosphorylation at Y490 $(a)$ and Y674/675 $(b)$ was assessed by immunoblot analysis with phosphospecific antibodies to Trk (Segal et al., 1996). $c, d$, Intensity of the bands visualized by ECF and the Storm System was quantified using Imagequant and expressed as NGF-induced fold stimulation relative to vehicle control. Each data point represents pooled data from five or six experiments. Wilcoxon signed rank test was used to compare results at the two temperatures. ${ }^{*} p<0.05$.

30 min of NGF-stimulation (Fig. $4 b, d$ ). Combined results from all four clones are shown graphically in Figure $4, c$ and $d$. These data indicate that internalization selectively regulates ligand-induced phosphorylation or dephosphorylation of individual tyrosine residues on the Trk receptors and that the phosphorylation state of the activation loop domain sites is increased when the receptors are endocytosed.

Phosphorylation of the activation loop tyrosines (Y674 and Y675) is required for catalytic activity of the receptor tyrosine kinase (Coulier et al., 1990; Segal et al., 1996; Cunningham et al., 1997). Therefore, we predict that NGF-induced Trk receptor kinase activity, like phosphorylation at Y674/675, should be greater at the permissive than at the nonpermissive temperature. The catalytic kinase activity of Trk is indeed greater in cells stimulated with NGF for 15 or $30 \mathrm{~min}$ at the permissive $\left(33^{\circ} \mathrm{C}\right)$ than at the nonpermissive temperature $\left(39^{\circ} \mathrm{C}\right)$ (Fig. 5). Similar results were

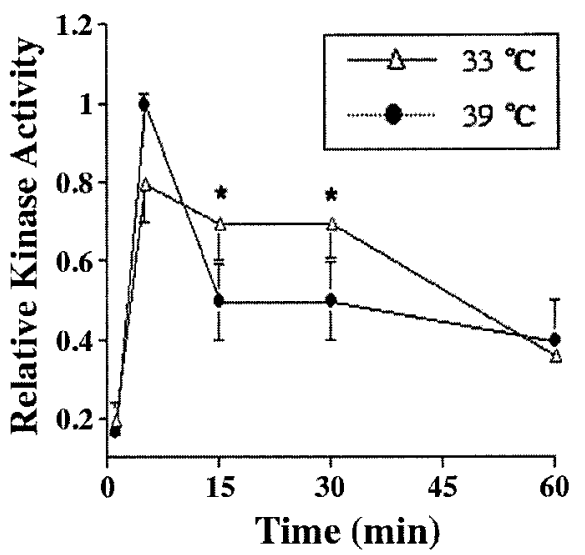

Figure 5. Internalization enhances catalytic kinase activity of Trk. Tsdynamin PC12 cells in serum-free medium were stimulated with NGF (+) or vehicle control ( - ) for the indicated times at the indicated temperature. Protein extracts were immunoprecipitated with anti-pan Trk and incubated with $\gamma^{32} \mathrm{P}$-ATP and Trk substrate peptide. Radioactivity incorporated into the Trk substrate peptides was quantified using the Storm System. Kinase activity was normalized to the maximal kinase activity in each experiment. Each data point represents the mean of five experiments \pm SEM. Wilcoxon signed rank test was used to compare results at the two temperatures. $*_{p}<0.05$.

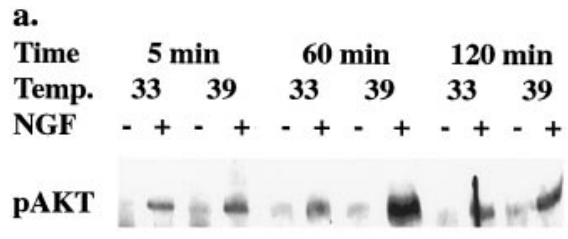

b.

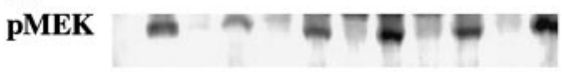

c.

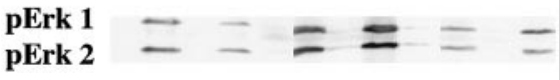

Figure 6. Phosphorylation of Akt, MEK-1, and Erk1 and Erk2 are modified by internalization. TS-dynamin PC12 cells in serum-free media were stimulated with NGF $(+\mathrm{NGF})$ or vehicle control $(-\mathrm{NGF})$ for the indicated times at the indicated temperatures. Phosphorylation of Akt $(a)$, MEK-1 $(b)$, or Erk1 and Erk2 (c) was assessed by immunoblot analysis with phosphospecific antibodies and visualized by enhanced chemifluorescence.

seen in all TS-dynamin clones but not in the WT-dynamin clones. Temperature does not affect the basal level of Trk catalytic activity. These data indicate that receptor endocytosis promotes liganddependent catalytic activity of the Trk receptors and may thereby increase NGF-induced differentiation.

As a control we evaluated the total level of Trk protein at the permissive and nonpermissive temperatures. Over the $2 \mathrm{hr}$ of treatment, NGF did not lead to any significant difference in the total Trk protein at either the permissive or nonpermissive temperature (total Trk protein at $2 \mathrm{hr}$ of NGF stimulation/total Trk protein at time 0 is $1.1 \pm 0.1$ at $33^{\circ} \mathrm{C}$ and $1.3 \pm 0.1$ at $39^{\circ} \mathrm{C}$ ).

\section{Internalization terminates PI3 kinase pathway signaling}

To investigate the mechanism whereby endocytosis decreases NGF-dependent survival, we analyzed the PI3 kinase/Akt pathway, which has previously been implicated in NGF-dependent survival (Yao and Cooper, 1995; Dudek et al., 1997; Downward, 1998). As shown in Figures 6 and 7, internalization influences Akt activation. At early times after NGF stimulation, Akt is similarly activated at both the permissive and nonpermissive temperatures. However, Akt activation persists longer when receptors remain at the plasma membrane: $2 \mathrm{hr}$ after NGF stimulation, there is persistent activa- 


\section{a. 5 minutes}

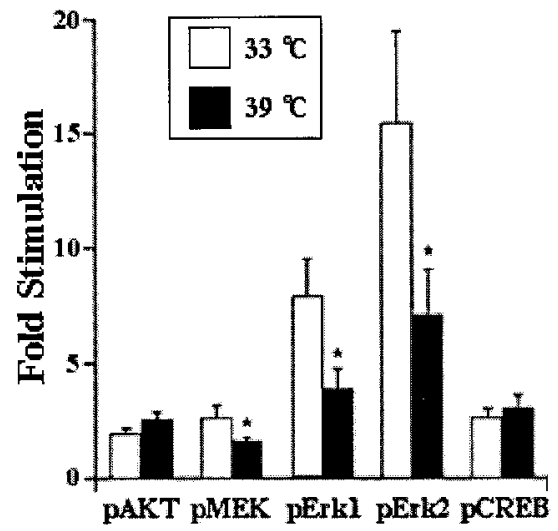

b. 2 hours

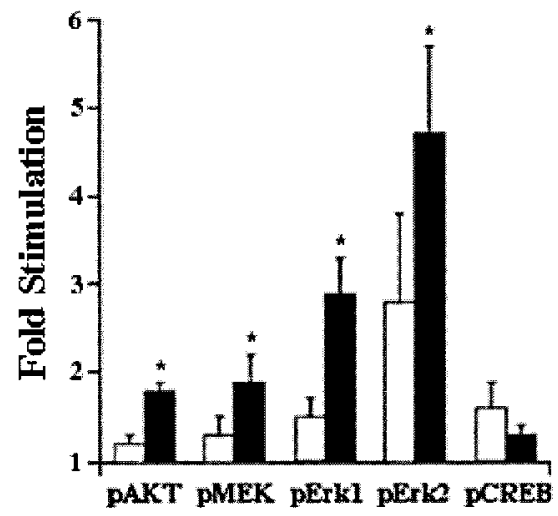

Figure 7. Internalization terminates Akt activation but has dual effects on the Ras-MAPK pathway. TS-dynamin PC12 cells in serum-free media were stimulated with NGF or vehicle control for $5 \mathrm{~min}$, or $2 \mathrm{hr}$, at the indicated temperatures. Intensities of p-Akt, p-MEK, p-Erk1, p-Erk2, and p-CREB were quantified using Imagequant and expressed as fold induction relative to the relevant vehicle control, after correction for protein loading. Each data point represents mean values from five or six experiments \pm SEM. Wilcoxon signed rank test was used to compare results at the two temperatures. ${ }^{*} p<0.05$.

tion of Akt at the nonpermissive temperature $\left(39^{\circ} \mathrm{C}\right)$ but not at the permissive temperature $\left(33^{\circ} \mathrm{C}\right)$. These data indicate that Trk internalization terminates the PI3 K/Akt signaling pathway and may explain the improved survival seen at the nonpermissive temperature when Trk cannot be internalized.

\section{Internalization alters the temporal pattern of Ras/ mitogen-activated protein kinase activation}

The time course of Ras/mitogen-activated protein kinase (MAPK) pathway activation is critical for biological responses to NGF (Qiu and Green, 1992; Traverse et al., 1992, 1994; Marshall, 1995). As shown in Figures 6 and 7, NGF-induced activation of MEK-1 and of the mitogen activated protein kinases Erk1 and Erk2 occurs at both the permissive and nonpermissive temperatures. After $5 \mathrm{~min}$ of stimulation with NGF, MEK-1 activation is greater at the permissive temperature $\left(33^{\circ} \mathrm{C}\right)$ than at the nonpermissive temperature $\left(39^{\circ} \mathrm{C}\right)$ (Figs. 6, 7). Similar results are seen for activation of Erk1 and Erk2, the kinases downstream of MEK-1 (Avruch et al., 1994) (Figs. 6, 7). However, NGF-induced activation of MEK and Erks persists longer when receptors remain at the plasma membrane: $2 \mathrm{hr}$ after NGF stimulation, there is greater activation of $\mathrm{MEK}$ and Erk1 and Erk2 at the nonpermissive temperature $\left(39^{\circ} \mathrm{C}\right)$ than at the permissive temperature $\left(33^{\circ} \mathrm{C}\right)$ (Figs. 6, 7). In contrast, phosphorylation of the transcription factor cAMP response element-binding (CREB) protein is not affected by internalization at any time point (Fig. 7). These data indicate that internalization functions to regulate the temporal pattern of NGF-induced Erk activation: internalization increases the peak level but shortens the duration of Erk activation.

\section{DISCUSSION}

\section{Trk internalization requires dynamin}

Studies on NGF internalization have demonstrated that internalized NGF can be found in various intracellular vesicles. These include coated vesicles, multivesicular bodies, lysosomes, and caveolae (Claude et al., 1982; Grimes et al., 1996, 1997). However, little is known about the molecular events that occur during internalization of NGF and its receptor. Here we demonstrate that internalization of NGF and ligand-induced internalization of Trk receptor require activity of dynamin, the GTP-binding protein that pinches off clathrin-coated vesicles from the plasma membrane (Baba et al., 1995; De Camilli et al., 1995). We do not detect any difference in the basal level of Trk internalization when dynamin is inhibited, indicating that dynamin is required for liganddependent, but not for ligand-independent, internalization of Trk receptors. The effect of mutant dynamin on internalization suggests that NGF-Trk complexes, like other ligand-receptor tyrosine kinases, are recruited and endocytosed into clathrin-coated vesicles after NGF stimulation. Although recent studies have implicated dynamin in caveolae internalization (Henley et al., 1998; Oh et al., 1998), our data are most consistent with NGF-Trk internalization into coated vesicles.

\section{Functions of Trk internalization}

NGF-mediated survival is optimal when the receptors remain at the plasma membrane. However, opposite results are seen for two measures of NGF-induced differentiation-neurite outgrowth and peripherin induction-indicating that internalized receptors are needed for optimal neuronal differentiation in response to NGF. A dichotomy between the survival and differentiation functions of NGF was also observed when the response to a rapidly internalized NGF-antibody complex was examined (Saragovi et al., 1998). The rapidly internalized complex was fully capable of promoting survival but did not promote neurite outgrow th (Saragovi et al., 1998). These findings are consistent with the results reported here, because the rapidly internalized NGF-antibody complex is likely to be targeted differently than the usual endocytosed receptors. The receptors activated by this NGF-antibody complex may not reach the signaling endosomes required for NGF-dependent neurite outgrowth.

Mutations in TrkA at a conserved KFG sequence (Peng et al., 1995), or at the nearby NP motif (Meakin and MacDonald, 1998), also have distinct effects on differentiation and survival. These mutations prevent NGF-induced neurite outgrowth without inhibiting NGF-dependent survival. Both mutations are in the juxtamembrane domain, and one of these mutations alters an NPXY motif that is often implicated in internalization (Boll et al., 1996). The biological responses of stimulating these mutant receptorssurvival without differentiation-are similar to the biological responses observed here when Trk receptor internalization is inhibited by the dynamin mutant. Therefore, we hypothesize that the KFG and NP mutant receptors may not be able to promote NGF-dependent differentiation because they are not internalized into the appropriate signaling endosomes.

Mutant dynamin can affect other cellular processes in addition to Trk internalization, and so we cannot exclude the possibility that the effects of dynamin mutations on neurite outgrowth could reflect a role for dynamin in the physical process of neurite extension (Torre et al., 1994). However, NGF-induced peripherin expression, an independent measure of differentiation (Troy et al., 1992), is also significantly better at the permissive temperature. Furthermore, the effect of endocytosis on differentiation is independent of proliferation. These data suggest that surface membraneembedded and vesicle-associated Trk receptors have distinct abilities to initiate NGF-induced differentiation and NGF-induced survival. 


\section{Intracellular location of activated receptors regulates signal transduction pathways}

The divergent effects of internalization on differentiation and survival suggest that receptors located at the plasma membrane, and those located on intracellular endosomes, might differentially activate downstream signaling pathways. We have found this to be the case. When we analyzed receptor phosphorylation, we found that phosphorylation of Y674/675 in the activation loop of the receptor is greater when the receptors can be internalized. In contrast, phosphorylation at the Y490 Shc binding site is not affected by internalization. Thus individual sites of phosphorylation are differentially affected by internalization. Internalization of the EGF receptor also affects receptor tyrosine phosphorylation, with phosphorylation of the PLC $\gamma$ interacting site being most sensitive to endocytosis (Vieira et al., 1996; Haugh et al., 1999). Taken together, these studies indicate that phosphorylation at individual tyrosines, rather than overall phosphorylation state, is regulated by the intracellular location of activated receptor tyrosine kinases.

Phosphorylation at the activation loop sites correlates with catalytic activity (Coulier et al., 1990; Segal et al., 1996; Cunningham et al., 1997). Here we show that endocytosed Trk receptors are phosphorylated at activation loop tyrosines and remain catalytically active. Furthermore, the temporal pattern of Trk activationloop phosphorylation correlates well with Trk kinase activity (compare Figs. $4 c$ and 5). Similarly, vesicle-associated insulin receptors show greater catalytic activity than membrane receptors (Drake et al., 1996). However, the activation loop sites may have functions that extend beyond regulating catalytic activity. Phosphorylation at the activation loop sites is both necessary and sufficient for NGFinduced activation of the Trk substrates r-APS and SH2-B, two signaling molecules implicated in neurotrophin-induced neurite outgrowth (Qian et al., 1998). The preferential phosphorylation of endocytosed Trk receptors at activation loop sites may allow optimal activation of r-APS and SH2-B and thereby promote neurite outgrowth and neuronal differentiation.

Although phosphorylation of the activation loop sites is greater when Trk receptors are internalized into vesicles, phosphorylation at the Y490 Shc binding site is not affected by internalization. However, the Ras/MAPK pathway that is largely triggered by Y490 phosphorylation (Stephens et al., 1994) is influenced by internalization. In previous studies (Watson et al., 1999b), we inhibited Trk glycosylation to prevent the receptors from reaching the plasma membrane. Unglycosylated Trk receptors accumulate at high density on intracellular vesicles, where they are constitutively phosphorylated, but are unable to activate the Ras/MAPK pathway. Here we again find that the location of activated Trk receptors is critical for activation of the Ras/MAPK pathway. Internalized Trk receptors, like internalized EGF or insulin receptors (Vieira et al., 1996; Ceresa et al., 1998), induce a higher peak level of Erk activation than do cell surface receptors. However, internalized Trk receptors induce briefer Erk activation than receptors that remain at the plasma membrane. Our studies therefore demonstrate that receptor localization is a critical regulator of the temporal pattern of Ras/MAPK activation, a key feature in NGFinduced differentiation (Marshall, 1995). Studies in non-neuronal cells using a dominant negative dynamin mutant (K44A) have shown that the dominant negative dynamin mutant blocks signaling from MEK to Erks (Kranenburg et al., 1999). In contrast, in the experiments shown here, the temperature-sensitive dynamin mutant had parallel effects on MEK and Erk activation. Thus the TS-dynamin mutant acts upstream of MEK to alter Erk activity in PC12 cells, indicating that the altered kinetics of Erk pathway activation at the nonpermissive temperature reflect inhibition of Trk receptor endocytosis.

Phosphorylation of Trk receptor at Y490 is also a trigger for activation of the PI3 kinase/Akt pathway critical for neuronal survival. Trk receptors that remain at the plasma membrane induce a long-lasting activation of Akt (Figs. 6, 7). Because constitutive activation of Akt has previously been shown to be sufficient for PC12 cell survival, this provides a potential explanation for our observations that NGF-mediated survival is optimal when the receptors remain at the plasma membrane.

On the basis of our findings, we suggest the following model. At the plasma membrane, receptors become activated and tyrosinephosphorylated. The plasma membrane-embedded receptors initiate the PI3 kinase/Akt pathway, which is critical for neuronal survival. After ligand binding, activated receptors are endocytosed into coated vesicles by dynamin-mediated endocytosis. Within vesicles, receptors remain catalytically active, and phosphorylated, because they are less accessible to membrane-embedded phosphatases (Tisi et al., 2000). Thus the internalized receptors are able to optimally activate substrates necessary for differentiation, such as $\mathrm{SH} 2-\mathrm{B}$ and r-APS. However, receptors within vesicles have poor access to lipid substrates and so no longer engender phospholipids to activate Akt. Therefore the endocytosed receptors are not able to initiate an optimal survival response. These data indicate that the signaling pathways and biological responses evoked by neurotrophins are dictated both by phosphotyrosine motifs within the receptors and by the intracellular location of phosphorylated receptors.

Although the studies here have all been performed in PC12 cells, the findings are of particular importance for the response of neurons to trophic factors in vivo. Neurotrophins can be released either by target cells or by presynaptic neurons (Altar et al., 1997; Conner et al., 1998), but internalization of receptors is required only for responses to target-derived neurotrophins (Riccio et al., 1997). If internalization changes the biological responses elicited by NGF, then target-derived and presynaptic factors may elicit distinct effects in the intact animal.

\section{REFERENCES}

Aletta JM, Angeletti R, Liem RK, Purcell C, Shelanski ML, Greene LA (1988) Relationship between the nerve growth factor-regulated clone 73 gene product and the 58-kilodalton neuronal intermediate filament protein (peripherin). J Neurochem 51:1317-1320.

Altar CA, Cai N, Bliven T, Juhasz M, Conner JM, Acheson AL, Lindsay RM, Wiegand SJ (1997) Anterograde transport of brain-derived neurotrophic factor and its role in the brain. Nature 389:856-860.

Avruch J, Zhang XF, Kyriakis JM (1994) Raf meets Ras: completing the framework of a signal transduction pathway. Trends Biochem Sci 19:279-283.

Baba T, Damke H, Hinshaw JE, Ikeda K, Schmid SL, Warnock DE (1995) Role of dynamin in clathrin-coated vesicle formation. Cold Spring Harb Symp Quant Biol 60:235-242.

Beattie EC, Zhou J, Grimes ML, Bunnett NW, Howe CL, Mobley WC (1996) A signaling endosome hypothesis to explain NGF actions: potential implications for neurodegeneration. Cold Spring Harbor Symp Quant Biol 61:389-406.

Bergeron JJ, Di Guglielmo GM, Baass PC, Authier F, Posner BI (1995) Endosomes, receptor tyrosine kinase internalization and signal transduction. Biosci Rep 15:411-418.

Bhattacharyya A, Watson FL, Bradlee TA, Pomeroy SL, Stiles CD, Segal RA (1997) Trk receptors function as rapid retrograde signal carriers in the adult nervous system. J Neurosci 17:7007-7016.

Boll W, Ohno H, Songyang Z, Rapoport I, Cantley LC, Bonifacino JS, Kirchhausen T (1996) Sequence requirements for the recognition of tyrosine-based endocytic signals by clathrin AP-2 complexes. EMBO J $15: 5789-5795$.

Ceresa BP, Kao AW, Santeler SR, Pessin JE (1998) Inhibition of clathrinmediated endocytosis selectively attenuates specific insulin receptor signal transduction pathways. Mol Cell Biol 18:3862-3870.

Chao MV (1992) Neurotrophin receptors: a window into neuronal differentiation. Neuron 9:583-593.

Claude P, Hawrot E, Dunis DA, Campenot RB (1982) Binding, internalization, and retrograde transport of 125I-nerve growth factor in cultured rat sympathetic neurons. J Neurosci 2:431-442.

Conner JM, Lauterborn JC, Gall CM (1998) Anterograde transport of neurotrophin proteins in the CNS: a reassessment of the neurotrophic hypothesis. Rev Neurosci 9:91-103.

Coulier F, Kumar R, Ernst M, Klein R, Martin-Zanca D, Barbacid M (1990) Human trk oncogenes activated by point mutation, in-frame deletion and duplication of the tyrosine kinase domain. Mol Cell Biol 10:4202-4210.

Cunningham ME, Stephens RM, Kaplan DR, Greene LA (1997) Autophosphorylation of activation loop tyrosines regulates signaling by the TRK nerve growth factor receptor. J Biol Chem 272:10957-10967.

Damke H, Baba T, van der Bliek AM, Schmid SL (1995) Clathrinindependent pinocytosis is induced in cells overexpressing a temperature-sensitive mutant of dynamin. J Cell Biol 131:69-80. 
De Camilli P, Takei K, McPherson PS (1995) The function of dynamin in endocytosis. Curr Opin Neurobiol 5:559-565.

Downward J (1998) Ras signalling and apoptosis. Curr Opin Genet Dev $8: 49-54$.

Drake PG, Bevan AP, Burgess JW, Bergeron JJ, Posner BI (1996) A role for tyrosine phosphorylation in both activation and inhibition of the insulin receptor tyrosine kinase in vivo. Endocrinology 137:4960-4968.

Dudek H, Datta SR, Franke TF, Birnbaum MJ, Yao R, Cooper GM, Segal RA, Kaplan DR, Greenberg ME (1997) Regulation of neuronal survival by the serine-threonine protein kinase Akt. Science 275:661-665.

Ehlers M, Kaplan D, Price D, Koliatsos V (1995) NGF-stimulated retrograde transport of trk A in the mammalian nervous system. J Cell Biol 130:149-156.

Eveleth DD, Bradshaw RA (1992) Nerve growth factor nonresponsive pheochromocytoma cells: altered internalization results in signaling dysfunction. J Cell Biol 117:291-299.

Gavrieli Y, Sherman Y, Ben SS (1992) Identification of programmed cell death in situ via specific labeling of nuclear DNA fragmentation. J Cell Biol 119:493-501.

Greene L, Tischler A (1982) PC12 Pheochromocytoma cultures in neurobiological research. Adv Cell Neurobiol 3:373-414.

Grimes M, Zhou J, Beattie E, Yuen E, Hall D, Valletta J, Topp K, LaVail J, Bunnett N, Mobley W (1996) Endocytosis of activated TrkA: evidence that nerve growth factor induces formation of signaling endosomes. J Neurosci 16:7950-7964.

Grimes ML, Beattie E, Mobley WC (1997) A signaling organelle containing the nerve growth factor-activated receptor tyrosine kinase, TrkA. Proc Natl Acad Sci USA 94:9909-9914.

Haugh JM, Schooler K, Wells A, Wiley HS, Lauffenburger DA (1999) Effect of epidermal growth factor receptor internalization on regulation of the phospholipase C-gamma1 signaling pathway. J Biol Chem 274:8958-8965.

Henley JR, Krueger EW, Oswald BJ, McNiven MA (1998) Dynaminmediated internalization of caveolae. J Cell Biol 141:85-99.

Hosang M, Shooter EM (1985) Molecular characteristics of nerve growth factor receptors on PC12 cells. J Biol Chem 260:655-662.

Kranenburg O, Verlaan I, Moolenaar W (1999) Dynamin is required for the activation of mitogen-activated protein (MAP) kinase by MAP kinase kinase*. J Biol Chem 274: 24575-24578.

Lemmon MA, Schlessinger J (1994) Regulation of signal transduction and signal diversity by receptor oligomerization. Trends Biochem Sci 19:459-463.

Marshall CJ (1995) Specificity of receptor tyrosine kinase signaling: transient versus sustained extracellular signal-regulated kinase activation. Cell 80:179-185.

Meakin SO, MacDonald JI (1998) A novel juxtamembrane deletion in rat TrkA blocks differentiative but not mitogenic cell signaling in response to nerve growth factor. J Neurochem 71:1875-1888.

Oh P, McIntosh DP, Schnitzer JE (1998) Dynamin at the neck of caveolae mediates their budding to form transport vesicles by GTP-driven fission from the plasma membrane of endothelium. J Cell Biol 141:101-114.

Peng X, Greene LA, Kaplan DR, Stephens RM (1995) Deletion of a conserved juxtamembrane sequence in Trk abolishes NGF-promoted neuritogenesis. Neuron 15:395-406.

Qian X, Riccio A, Zhang Y, Ginty D (1998) Identification and characterization of novel substrates of Trk receptors in developing neurons. Neuron 21:1017-1029.
Qiu M, Green S (1992) PC12 cell neuronal differentiation is associated with prolonged p21 ras activity and consequent prolonged ERK activity. Neuron 9:705-717.

Riccio A, Pierchala BA, Ciarallo CL, Ginty DD (1997) An NGF-Trkamediated retrograde signal to transcription factor CREB in sympathetic neurons. Science 277:1097-1100.

Saragovi HU, Zheng W, Maliartchouk S, DiGugliemo GM, Mawal YR, Kamen A, Woo SB, Cuello AC, Debeir T, Neet KE (1998) A TrkAselective, fast internalizing nerve growth factor-antibody complex induces trophic but not neuritogenic signals. J Biol Chem 273:34933-34940.

Schwartz P, Borghesani P, Levy R, Pomeroy S, Segal R (1997) Abnormal cerebellar development and foliation in $\mathrm{BDNF}-1-$ mice reveals a role for neurotrophins in CNS patterning. Neuron 19:269-281.

Segal R, Bhattacharyya A, Rua L, Alberta J, Stephens R, Kaplan D, Stiles C (1996) Differential utilization of Trk autophosphorylation sites. J Biol Chem 271:20175-20181.

Senger DL, Campenot RB (1997) Rapid retrograde tyrosine phosphorylation of TrkA and other proteins in rat sympathetic neurons in compartmented cultures. J Cell Biol 138:411-421.

Stephens RM, Loeb DM, Copeland TD, Pawson T, Greene LA, Kaplan DR (1994) Trk receptors use redundant signal transduction pathways involving SHC and PLC-gamma 1 to mediate NGF responses. Neuron 12:691-705.

Tisi M, Xie Y, Yeo T, Longo F (2000) Downregulation of LAR tyrosine phosphatase prevents apoptosis and augments NGF-induced neurite outgrowth. J Neurobiol 42:477-486.

Torre E, McNiven MA, Urrutia R (1994) Dynamin 1 antisense oligonucleotide treatment prevents neurite formation in cultured hippocampal neurons. J Biol Chem 269:32411-32417.

Traverse S, Gomez N, Paterson H, Marshall C, Cohen P (1992) Sustained activation of the mitogen-activated protein (MAP) kinase cascade may be required for differentiation of PC12 cells. Comparison of the effects of nerve growth factor and epidermal growth factor. Biochem $J$ 288:351-355.

Traverse S, Seedorf K, Paterson H, Marshall CJ, Cohen P, Ullrich A (1994) EGF triggers neuronal differentiation of PC12 cells that overexpress the EGF receptor. Curr Biol 4:694-701.

Troy CM, Greene LA, Shelanski ML (1992) Neurite outgrowth in peripherin-depleted PC12 cells. J Cell Biol 117:1085-1092.

Tsui-Pierchala BA, Ginty DD (1999) Characterization of an NGF-P-trkA retrograde-signaling complex and age-dependent regulation of TrkA phosphorylation in sympathetic neurons. J Neurosci 19:8207-8218.

Vieira AV, Lamaze C, Schmid SL (1996) Control of EGF receptor signaling by clathrin-mediated endocytosis. Science 274:2086-2089.

Watson FL, Heerssen HM, Moheban DB, Lin MZ, Sauvageot CM, Bhattacharyya A, Pomeroy SL, Segal RA (1999a) Rapid nuclear responses to target-derived neurotrophins require retrograde transport of ligandreceptor complex. J Neurosci 19:7889-7900.

Watson FL, Porcionatto MA, Bhattacharyya A, Stiles CD, Segal RA (1999b) TrkA glycosylation regulates receptor localization and activity. J Neurobiol 39:323-336.

Yao R, Cooper G (1995) Requirement for phosphatidylinositol-3 kinase in the prevention of apoptosis by nerve growth factor. Science 267:20032006. 